\title{
P05.38. Experiences and wishes from cancer children and their families regarding CAM (complementary and alternative therapies)
}

\author{
L Eriksen
}

From International Research Congress on Integrative Medicine and Health 2012

Portland, Oregon, USA. 15-18 May 2012

\section{Purpose}

To illuminate children with cancer and their families' experiences and wishes regarding CAM, and to develop a model for data collection, which may be internationally useful.

\section{Methods}

An exploratory approach using mixed methods was done in two phases. Phase One: Focus group consisting of families of children with cancer. Exchange of experiences based on 7 questions regarding traditional / conventional and CAM treatment. Phase Two: Completion of an anonymous questionnaire, also containing 7 questions.

\section{Results}

With a representation of 51 families of children with cancer, 26 questionnaires were returned (13 boys and 13 girls), corresponding to a $51 \%$ response. In addition, 5 forms were received, completed by adults (data analysis is currently taking place, November 2011).

\section{Conclusion}

We know very little about which CAM treatments work and how they work. Families of children with cancer have experiences with CAM and want access to sober objective user information. They also wish to see CAM being integrated within the health services as a supplement to conventional treatment (Detailed information will be available at the ICCMR Congress May 2012).

Published: 12 June 2012

$\overline{\text { CareCam - FCB, Association of Cancer Children in DK, Vallensbaek, Denmark }}$
doi:10.1186/1472-6882-12-S1-P398

Cite this article as: Eriksen: P05.38. Experiences and wishes from cancer children and their families regarding CAM (complementary and alternative therapies). BMC Complementary and Alternative Medicine 2012 12(Suppl 1):P398.
Submit your next manuscript to BioMed Central and take full advantage of:

- Convenient online submission

- Thorough peer review

- No space constraints or color figure charges

- Immediate publication on acceptance

- Inclusion in PubMed, CAS, Scopus and Google Scholar

- Research which is freely available for redistribution 